\title{
COVID-19 Pandemisinin İnsan Kaynakları Üzerindeki Etkisinin Akademi, Medya ve İş Dünyası Perspektifinden İncelenmesi ${ }^{1}$
}

\author{
Gülșen KIRPIK ${ }^{2}$
}

Öz

COVID-19 Pandemisi sebebiyle, çalışma koşullarının nasıl değiştiği veya gelecekte nasıl değişeceği konusu ulusal ya da uluslararası düzeyde bilimsel araştırmalar, televizyon programları, gazete haberleri, online toplantılar ve benzeri çalışmalar ile güncel olarak üzerinde tartışılan önemli konular arasındadır. Bu çalışmanın amacı, küresel anlamda yaşanan COVID-19 pandemisinin insan kaynakları üzerindeki etkisinin ne olduğunun ya da gelecekte nasıl etkileyebileceğinin ortaya konmasıdır. Bu bağlamda, akademi, medya ve iş dünyasındaki online görüşler ve yayınlar üzerinden nitel bir inceleme yapılmıştır. Literatür taraması sırasında araştırmaya dahil edilme ve hariç tutulma kriterleri uygulanmıştır. Ulaşılan akademik çalışmalar ile haber, görüş ve önerilerden yararlanılarak insan kaynağının nasıl etkilendiği ya da etkilenebileceği tümevarımsal olarak değerlendirilmiştir. COVID-19 pandemisiyle birlikte, "evden çalışma", "ücretli / ücretsiz izinlerin kullanılması", "işsizliğin ortaya çıkışı", "dijital çalışan, açık yaka çalışan ya da gri yakalı çalışanların öneminin artması", "işletmelerin iflası", "göçmen işçilerin sorunları" ve diğer bulgulara ulaşılmıştır. Bu bağlamda, yöneticilere, çalışanlara, araştırmacılara ve diğer ilgililere öneriler sunulmuştur.

Anabtar Kelimeler: COVID-19 Pandemisi, İnsan Kaynakları, İş Dünyası

\section{Investigation of the Effect of COVID-19 Pandemic on Human Resources from the} Perspective of the Academy, Media and Business World

\begin{abstract}
Due to the COVID-19 Pandemic, the issue of how working conditions change or how it will change in the future is among the important issues that are currently being discussed with scientific research, television programs, newspaper news, online meetings and similar studies at national or international level. The aim of this study is to reveal the impact of the globally occurring COVID-19 pandemic on human resources or how it may affect the future. In this context, a qualitative review has been made through online opinions and publications in academia, the media and the business world. During the literature review, the criteria for inclusion and exclusion were applied. Using academic studies, news, opinions and suggestions, it has been evaluated inductively how human resources are affected or may be affected. Together with the COVID-19 pandemic, "working from home", "using paid / unpaid leave", "emergence of unemployment", "increasing importance of digital workers, open collar or gray collar employees", "bankruptcy of businesses", "problems of migrant workers" and other findings were reached. In this context, suggestions were presented to managers, employees, researchers and other interested people.
\end{abstract}

Key Words: COVID-19 Pandemic, Human Resources, Business World

Atıf İçin / Please Cite As:

Kırpık, G. (2020). COVID-19 Pandemisinin insan kaynakları üzerindeki etkisinin akademi, medya ve iş dünyası perspektifinden incelenmesi. Manas Sosyal Arastırmalar Dergisi, 9(4), 2393-2406.

Geliş Tarihi / Received Date: 25.06.2020

Kabul Tarihi / Accepted Date: 25.08.2020

\footnotetext{
${ }^{1}$ Bu çalışma, 12-13-14 Haziran 2020 Tarihlerinde düzenlenen Online International Conference of COVID-19 (CONCOVID)'de sözlü olarak sunulmuștur.

2 Dr. Öğr. Üyesi - Türkiye-Adıyaman Üniversitesi Eczacllık Fakültesi, gkirpik@adiyaman.edu.tr ORCID: 0000-0003-4785-9624
} 


\section{Giriş}

2020 yllı ülkemiz ve tüm dünya ülkeleri açısından zorluklarla başlamıştır. Ülkemiz açısından 11 Ocak (Silivri'de 4.9 şiddetinde) ve 24 Ocak (Elazı ğ'da 6.8 şiddetinde) tarihlerindeki depremler, 4-5 Şubat tarihlerinde yaşanılan Van çı̆̆ faciası, 5 Şubat tarihinde Pegasus Hava Yollarının uçağının pistten çıkması, 23 Şubat tarihinde yaşanan Türkiye-İran depremleri ve 11 Mart tarihinde ilk korona virüs vakasının tespiti gibi olaylar (URL-1) örnek olarak verilebilir. Dünyada ise Johnson Yap (2020) tarafindan da belirtildiği üzere, rekor kıran sıcaklıklar ve aylarca süren şiddetli kuraklığın Avustralya genelinde bir dizi büyük orman yangınını körüklemesi ve 2019 sonunda ölümcül bir hastalık olan COVID-19 pandemisinin küresel bir salgin haline gelmesi örnek olarak gösterilebilir. Stephens’e (2020, s. 76) göre "Dünya değişiyor ve nasıl ilerlediğimizi görmek ilginç olacak".

Çok kısa sürede ve çok daha hızlı olumsuz sonuçları olan "Yeni Koronavirüs Hastalı̆̆ı" olarak adlandır1lan: COVID-19, Dünya Sağlık Örgütü tarafindan (URL-2), 12 Mart 2020' de pandemi ve küresel sağllk tehdidi (Şen, 2020, s. 177) olarak ilan edilmiştir. Lahtinen (2020) tarafindan da belirtildiği üzere, insanlık küresel bir krizle karşı karşıyadır. COVID-19 krizini takiben ülkeler arasında iş birliği ortaya çıkmıştır. Ülkeler, hükümetler, bilim adamlan, şirketler, topluluklar ve bireyler arasında etkili, kapsamlı ve tarafsız iş birliğinin sadece koronavirüs için değil, aynı zamanda iklim değişikliği gibi dünyanın diğer büyük zorluklarını aşmak için de zafer getirmesi beklenmektedir.

İş dünyası küresel, ekonomik, sosyokültürel, demografik, politik ve teknolojik olmak üzere çeşitli dış faktörlerden doğrudan etkilenmektedir. Bu faktörlerdeki değişiklikler, tüm sektörlerdeki iş performansında ve buna bağlı diğer örgütsel sonuçlarda etkili olacaktır (Wen, Kozak, Yang ve Liu, 2020). 2019' un sonlarında Wuhan Çin'de başlayan Coronavirus (COVID-19) pandemisi, küresel ekonomiyi engelleyen karantina nedeniyle hem gelişmiş hem de gelişmekte olan ülkeleri büyük ölçüde etkilemiştir (John-Eke ve Eke, 2020, s. 38). Dolayısıyla, COVID-19 pandemisinin küresel anlamda iş dünyası ve insan kaynakları üzerinde çok boyutlu düzeyde etki ve değişikliklere sebep olacağ söylenebilir.

COVID-19 pandemisi sebebiyle, tarafindan, çalışanların işten çıkarıldığı ya da izine gönderildiği (Stephens, 2020, s. 89) bilinmektedir. COVID-19 pandemisinin kesin süresi şu anda bilinmemektedir (Perold, Bruwer ve Hattingh, 2020). Küresel düzeyde büyük bir belirsizlik olduğu, her şeyin ne zaman normale döneceğinin bilinmediği ve bu nedenle piyasada uzun süre istikrarsızlık ve güven eksikliği olacağı öngörülmektedir. Bu bağlamda, istihdam ve gelirlerin desteklenmesi amacıyla, çalışılmayan süreler kısmi işsizlik yardımları Fransa, Almanya (Kurzarbeit), İtalya ve Hollanda'da genişletilmiştir. İstihdamın korunması da diğer yollarla güvence altına alınmaktadır. Çin Hükümeti, hastalık veya kısıtlama önlemleri durumunda göçmen işçilerin sözleşmelerinin feshedilmemesini sağlayan tebliğ yayınlamıştır. Bazı ülkelerde işsizlik yardımları genişletilmiştir. Filipinler'de Sosyal Güvenlik Programı kapsamında, muhtemel işten çıkarma veya işletme kapanması nedeniyle işlerini kaybedecekleri tahmin edilen 60.000 civarı çalışana işsizlik yardımı ödeyecektir. Ayrıca, bazı ülkelerde gelir güvenliğini ve toplam talebi artırmak için sosyal yardımlar veya diğer nakit transferleri yapılmaktadır (URL-3).

Görüldüğü üzere, COVID-19 pandemisi, iş dünyasının kepenklenmeye zorlandığı (Wen vd., 2020) bir süreçtir. İş dünyasını eşi görülmemiş bir boyut ve hızda vurmuştur (Sengupta ve Bose, 2020, s. 201). Bu kriz daha önce benzeri görülmemiş, dünyadaki her insanı doğrudan etkileyen ilk ve tek krizdir, yıkıcıdır çünkü kriz ihmal edilmiştir ve etkisi ölümcül olabilir ve bu bağlamda çok iyi bir referanstır (John-Eke ve Eke, 2020, s. 43; Nastopoulous, 2020, s. 4). COVID-19'un olumsuz sonuçları işletmeleri savunmasız hale (Nguyen, 2020) getirmiştir. Bu süreç içerisinde, çoğu işletmenin faaliyetleri geçici olarak durdurulmuştur ve yalnızca temel hizmet sağlayan işletmelerin faaliyetlerine devam etmesine izin verilmiştir (Perold vd., 2020, s. 7). Diğer taraftan, COVID-19 pandemisinin gelecekteki yaratacağı en büyük sorunlardan biri de yöneticilerin çalışanlarıyla temasa geçememesi (Nastopoulous, 2020, s. 12) ya da çalışanların birbirleriyle iletişim kuramamaları olacaktır. Bu kriz ortamında, fiziksel bir yerde sağlık ve güvenliklerini garanti altına almaya çalışırken çalışanlar kendilerini nasıl rahat hissedebilirler? (Nastopoulous, 2020, s. 21) Bu yıkıc1 krizin iş dünyasına getirdiği önemli etkilerden bazlları nelerdir? (Ting, Ling ve Cheah, 2020, s. 2) gibi sorular iş dünyasında ve akademik dünyada akla gelen sorulardan bazılarıdır.

Bu çalışma, COVID-19 pandemisinin işletmelerin insan kaynağı üzerindeki etkilerinin incelenmesi amacıyla yapılmıştır. Bu bağlamda, 2019-2020 yılları arasında online yayınlanan akademik nitelikteki makaleler, tezler, kitap ya da kitap bölümleri ile online olarak yayınlanan iş dünyası görüşleri ve medya haberlerinden elde edilen veriler literatür taraması yöntemiyle analiz edilerek yorumlanmıs, özetlenmiş ve iş 
dünyasının yöneticileri başta olmak üzere gelecekteki araştırmacılara da yol gösterici önerilerde bulunulmuştur.

\section{Covıd 19 Pandemisinin İnsan Kaynakları Üzerindeki Etkisini İnceleyen Literatür Taramas1}

\section{Metodoloji ve Örneklem Seçimi}

Çalışmanın amacına ulaşmak için öncelikle literatür taraması yapılmıştır. Google arama motoruna "COVID 19", "business world", "employee" terimleri yazıldığında yaklaşık 767.000 (URL-4) yayına ulaşılmışır. Bu ana kütle içerisinde medyatik magazinsel, iş dünyası ya da akademik çalışmalar ile ilgili tüm yayınlar yer almaktadır. Ancak çalışmanın bilimsel niteliğinin ve kalitesinin artırlması amacıyla akademik yayınlara öncelik verilmiştir. Bu bağlamda, akademik çalışmalara yönelik Google Akademik veri tabanına aynı terimler yazılarak 62 (URL-5) akademik çalş̧̧maya ulaşılmıştır. Literatür taramasının güvenirliği açısından arama işlemi birkaç kez yinelenmiş ve sonuç yine 62 akademik yayın şeklinde olmuştur. Çalısmaların örnekleme dahil edilmesi ya da hariç tutulmasında "COVID 19", "business world", "employee / worker" kriterlerine göre makaleler incelenmiştir. İnceleme sonucunda, çalışmanın akademik çalışmalara yönelik örneklemini 14 akademik çalışma oluşturmuştur. Geri kalan 48 çalışmanın literatür analizine dahil edilmeme / edilememe gerekçeleri sırası ile ve ayrıntılı olarak verilmiştir. Şöyle ki;

a) Çalışmanın tam metin kısmında COVID-19 ibaresinin geçmesine rağmen erişimi ücrete tabi tutulan çalışmalar (Avni ve Rotem, 2020; BaniMelhem ve Elanain, 2020; Paché, 2020; Moaniba, Su ve Lee, 2020; Sharma, Moses, Borah ve Adhikary, 2020; Tan, 2020),

b) Literatür tarama sonuçlarında yer almasına rağmen içerik olarak COVID- 19 pandemisi ve / veya çalışanlar (işçi, personel, eleman gibi) yani insan kaynakları ile ilgili olmayanlar; Sağlık alanı ile ilgili olanlar: Aron, 2020; Bays, 2020; Johnson vd., 2013; Lancaster vd., 2020; Marks, 2020; Maves vd., 2020; McPhilemy vd., 2020) (Uluslararası Yönetim ile ilgili- Terpstra-Tong, 2020; Tüketici davranışıyla ilgiliFred ve William, 1977; Satış ile ilgili- Wayens vd., 2020; Liderlik ile ilgili- Ronay vd., 2020; Marka yönetimi ile ilgili- Hassan, 2020; Sosyal medya ile ilgili, Kim, 2017; İsletme sempozyumu ile ilgili- Wilson, 2020; Eğitim ve psikoloji ile ilgili- Lemmetty vd., 2020; Reynolds, 2020; Stork, 2019; Kriminoloji ile ilgili- Lewis, 2020; Örgütsel yenilik ile ilgili- Yadav, 2020; Liderlik ile ilgili- Levine, 2020; Kız1l, 2015; Sosyal adalet ile ilgili- Crosby vd., 2019; COVID-19 pandemisinden önce tamamlanan, motivasyon ve çalışan bağl1llğı ile ilgili- Söderholm, 2020; Lambros, 2020; Bilgisayar ve teknoloji ile ilgili- Richardson, 2020; Yönetim, maneiyat ve din ile ilgili- Chatterji, 2020; iş hayatında içedönüklük ile ilgili- Järvinen, 2020; Kariyer ile ilgiliBugarija, 2016; Nöropazarlama ile ilgili- Hsu ve Chen, 2020; Duygusal zeka ile ilgili- Gurdulić, 2019; Ishfaq, 2020; Girişimcilik ve yenilik ile ilgili- Blazynek vd., 2020; Tüketim malları ile ilgili- Wideman, 2020; Suriye'deki seçimlerle ilgili- Awad ve Favier, 2020; Rekabet ile ilgili- Simola, Räsänen ve Kettunen, 2020; Jeomühendislik ile ilgili- McGrath, 2013; Kurumsal yapılanma ile ilgili- Lovén, 2020; Kurumsal büyüme ve iş etiği ile ilgili- Singh, 2020),

c) Arama motoru sonuçları içerisinde olsa bile erişime pasif durumda olan çalışmalar (Mehrotra, 2020; 권혁 - 노동법논총, 2020),

d) Erişim hatası veren çalısmalar (Drake ve Drake-Error 403; Friedberg, Error 403) şeklinde siralanabilir.

Ancak bu çalşsmada sadece akademik görüşler değil aynı zamanda iş dünyasında ve medya haberlerinde yer alan görüşlere de yer verildiğinden, çalışmada 14 makale dışında konuya yönelik diğer elde edilen yayın ve çalışmalardan da yararlanılmıştır.

\section{Bulgular}

Çalışmada kullanılan akademik çalısmalardan, iş dünyası görüşlerinden ve medya haberlerinden elde edilen bulgular sırasıyla, akademik açıdan iş dünyası açısından ve medyatik açıdan ayrı ayrı verilmiştir.

Akademik. Açıdan COVID-19'un İnsan Kaynaklar Üzerindeki Etkisi. Dijital çağda strateji geliştirme ve çevik olma ile ilgili, Arno Ritter (2020) tarafindan yayınlanan "The TUDAPOL Principle: The Way to Think Unlimited, Develop Agile, Produce and Operate Lean" başlıklı kitap çalışması, COVID-19 pandemisinin yaşandığı bugünlerde iş dünyasının yöneticileri ve diğer ilgilileri için dikkat çeken en önemli ve güncel çalşsmalar arasında yerini almışır. Bu çalışmada ortaya konan “TUDAPOL İlkesi”nin önümüzdeki yıllarda üzerinde çok çalışılacak konular arasında yer alacağı söylenebilir. Çünkü, bu çalışmada 
COVID-19 gibi aniden ortaya çıkan ve küresel anlamda tüm işletmelerin etkilendiği krizlere yönelik, karmaşıklığın azaltılması, çevik stratejilerin geliştirilmesi üzerine odaklanılmıştır.

Küreselleşmenin, dijitalleşme kavramıyla etkileşimi sayesinde, tüm ekonomik politikalar, kültürler, toplumlar, insan grupları ve son olarak da birey üzerindeki etkilerini açıklayarak geleceğe yönelik tahminler yapılması hedeflenen, Şen (2020) tarafindan yapılan çalışmada, COVID-19 sebebiyle küresel sağlık krizinin etkilerinin ve olası sonuçlarının kavramsal ve teorik olarak incelenmesi amacıyla ilgili süreç "Senizm" teorisi açısından değerlendirilmiştir. Bununla birlikte, Şen (2020, s. 183) tarafindan COVID-19 krizinin yerel, ulusal ve küresel bazda yönetilmesi sürecinde, bunun en önemli örneklerinden biri, insanların "evde kalmaya" çağrilırken; birçok zorunlu ihtiyacın üretimi ve sunumu ve zorunlu olarak görülen, üretilmesi ve tüketime sunulması gereken bazı taleplerin de fabrikalardaki işçi bireyler tarafindan, yani "evlerinin dışında" yürütüldüğü vurgulanmıştır.

Koirala ve Acharya (2020, s. 1) tarafindan yapılan çalışmada ise, COVID-19'un mevcut sistemi, yani çalışma, egzersiz yapma, alışveriş yapma, iletişim kurma, eğitme ve öğrenme sistemini kıracağından, bu büyük işyeri dönüşümlerinden sorumlu tutulabileceği belirtilmiştir. Bu çalışmada, dönüşümün işletmeleri yavaş yavaş insan kaynakları politikalarında ve stratejilerinde değişiklik yapmaya zorlayacağı ve burada dikkat edilmesi gereken noktanın, tarihte yaratılan değişim faktörünün, "sosyal uzaklık" kavramı olduğu vurgulanmıştır. Evden çalışma, COVID-19'un patlak vermesiyle ortaya çıkan yeni bir kavram olup, bilgi iletişim sistemi tarafindan desteklenen esnek görev tabanlı çalışma kültürü yaklaşımıdır. Ancak, bu yaklaşım satış yönetimi, pazarlama, müşteri iletişimi vb. dışındaki imalat endüstrileri için uygun değildir. Hizmet endüstrileri için daha uygundur. Ancak, veri koruma, gizlilik, hat yönetimi, maaş bordrosu tabanları ve genişletilmiş iş yönetimi, bunun zorluklarıdır. Evden çalışma, görevlerin uygunluğuna bağlı olarak çalışanlara kendi rrzasıyla atanan yöntemdir Bununla birlikte, evden çalışmayı destekleyen, Stephens (2020, s. 76) tarafindan yapılan bir başka çalışmada, COVID-19'un sosyal mesafesi nedeniyle işletmelerin daha çok evden çalışma yönünde gelişeceği ve çalışanın doğrudan evden çalışması ile işletmelerin çok fazla tasarruf edebileceği belirtilmiştir. Dolayısıyla, COVID-19 pandemisi, insan kaynaklarının iş hayatını evden çalışmaya doğru genişletebilir. Bu sadece karantina dönemi için geçici kullanılan bir yöntem değil, aynı zamanda normalleşme dönemi için de kalıc insan kaynakları yönetim sistemi olabilir (Koirala ve Acharya, 2020, s. 6). Benzer bir şekilde, Simonen (2020, s. 67) tarafından yapılan çalışmada da mevcut koronavirüs pandemisi nedeniyle, Nisan 2020'nin başında, bir milyondan fazla Fin'in evden çalıştığı ve bunların yarısından fazlasının ise durum normale döndüğünde evden çalışmaya devam etmek istedikleri belirtilmiştir. Butler (2020, s. 2) tarafindan ise, özellikle uzaktan çalışanların işyerlerine döndüklerinde daha da değerli olacakları, ancak, uzun süre hiç çalışmayan veya evden çalışanlarda (özellikle potansiyel kalıntı kaygılar ve izolasyonla ilgili problemlerle işlerine döndüklerinde) sorunları tanıma yeteneğinin azalacağına yönelik kaygılardan bahsedilmiştir.

COVID-19 pandemisi sırasında işletmelerin sempati ve yardımseverliği üzerinde bir çalışma yapan, Ishak, Omar ve Osman (2020, s. 105) tarafindan da belirtildiği üzere, COVID-19 pandemisi dünyadaki neredeyse tüm ülkelerde hızla yaylmaya devam etmektedir. Bu nedenle, her ülke virüsün yayılmasını yavaşlatmak için karantina, sınırlama, hareket kontrolü ve sosyal uzaklaşma politikası gibi ciddi önleyici çabalar içerisindedir. Pandemik etki, sadece küresel nüfus sağlı̆ını değil, aynı zamanda sosyal, iş dünyası ve ekonomi üzerinde de devasa bir etkiye sahip olduğundan büyüktür. Benzer şekilde, Supardi ve Hadi (2020, s. 1265) tarafından yapılan çalışmada COVID-19 pandemisinin tüm işletmelerin ekonomik faaliyetlerinde bozulmaya sebep olduğu, bu nedenle işletmelerin işten çıkarmalar yapacağı, iflas tehdidiyle karşı karşıya oldukları ve hatta bunların bazılarının hayatta kalamadıkları için iflas ettiği belirtilmiştir. Ayrıca, bu pandemik krizin birçok örgütün stratejik hedeflerini "kâr arayışından" "dayanıklılık arayışına" (hem özümseyici hem de uyarlanabilir dayanıklılığ kapsayan) kaydırdığı ifade edilmiştir. COVID-19 nedeniyle dünyadaki insanların normlarının da değişmesinin beklendiği de belirtilmiştir. Buna göre, örneğin, virüse karşı savaşmak için önemli yaklaşımlardan biri, insanların daha önce sahip oldukları normal uygulamaları ve gelenekleri kısıtlamaktır. Ahlaki duyarlılık ile ilgili olduğu kadar, salgının, iş sektörlerinin ahlaki duygularını da aydınlatması beklenmektedir.

John Eke ve Eke (2020, s. 43) tarafindan yapılan çalışmada, kriz yönetiminin daha önce hiç bu kadar önemli olmadığ1 vurgulanmıştır. COVID-19 pandemisinin tüm dünyayı savunmasız hale getirdiği ve küresel ekonomiyi bozduğu, bu nedenle işletmelerde kriz yönetimi uzmanlarına ve stratejistlerine yüksek derecede ihtiyaç duyulduğu belirtilmiştir. Doğru stratejik planlama yoluyla, her yerdeki her işletmenin, kriz türünü ve kaynaklarını analiz edebilmesi ve tanımlaması ile uygun kriz yönetimi tarzını uygulayabileceği ifade edilmiştir. 
Ritter (2020, s. 111) tarafindan yürütülen çalışmada, "Etkileyen tüm faktörleri de bilmiyoruz. Clausewitz'i (savaş sisi) hatırlayın. COVID-19'u, Berlin Duvarı 09 Kasım 1989'un çöküşünü veya bazı tehlikeli buluşları kim bekledi? Ancak, prensipte bazı problemlere cevap verebilmeli ve bazı problemleri öngörebilmeliyiz. İşte bu meydan okuma! Ayrıca, yeni firsatların ve yeni (acil) stratejilerin olumlu yönünü de unutmayın." şeklindeki ifadeler COVID-19 krizindeki belirsizliklere rağmen risk ve firsat yönetimine verilmesi gereken öneme dikkat çekilmiştir.

Diğer taraftan, Haywood (2020, s. 4) ise COVID-19 pandemisine yönelik şöyle bir değerlendirme yapmıştır: "Bugün olduğu gibi: Herkes aynı teknede, belirsiz bir dünyada benzer ikilemlere ve bilmecelere bakiyor... her zaman kazanamayacak olsak da hepimiz arzu edilebilir, mümkün ve uygulanabilir seçenekler arıyoruz. Her işletme ve her insan anında yeniden adapte olmayı öğreniyor; daha sağlam finansal temeller elde etmek için çok çalışan herkes, çalışanların yeniden uyum sağlamasına yardımcı olmaktan endişe duymaktadır.” Bu görüşlerde de COVID-19 krizinin belirsizlik, bilmece ve ikilemleri üzerinde durulması, bu pandeminin endişe yarattı̆̆ının göstergesidir.

Şen (2020, s. 183) tarafindan, küresel sağlık krizinde, insan davranışları için iki farklı kutuptan bahsedilmişsir. "Ben ve Sen". "Ben” davranışı gösteren kişinin ilkel dürtülerine göre hareket eden, aniden stoklayan, korumaya çalışan, varlığını kurtarmaya çalışan özelliklere sahip iken, "Sen" davranışı gösteren bireyin ise koruma, bakma ve diğer insanlarla empati kurma gibi özelliklere sahip olduğu belirtilmiştir. Ayrica, "Gen Sen - Nesil Sen" adlandırmasının, gelecek nesillerden birinin yeni nesil sınıflandirmasi olabileceğinden de bahsedilmiştir. Benzer şekilde, milenyum kuşağı açısından COVID-19 krizini değerlendiren, Hultman (2020, s. 42) tarafindan yapılan çalışmada, Milenyum kuşağının sağlıklı bir iş / yaşam dengesi istediği, arkadaşlar, aile, egzersiz ve seyahat ile sosyalleşmek için zaman istedikleri ve bunun iş sorumluluklarını etkilemediğini düşündükleri belirtilmiştir. Bununla birlikte, aileden ve kişisel önceliklerinden önemli ölçüde uzaklaşmaları beklenirse, işten ayrılma olasılıklarının yüksek olduğu ifade edilmiştir. Ayrıca, COVID-19 pandemisinin, birçok çalışanı karantinaya aldığı, işin nasıl ve nerede yürütüleceğini zorunlu olarak değiştirdiği, bu yüzden işletmelerin temel işletim uygulamalarını ve prosedürlerini yeniden düzenlemeleri gerektiği de belirtilmiştir.

Ting ve diğerleri (2020, s. 4) tarafindan yapılan çalışmada, bir hafta önce Amerika'da sadece 10 milyon çalışanın işsizlik endişesi yaşarken bir hafta sonra bu rakamın 22 milyona ulaştığı belirtilmiştir. Buna göre, COVID-19 salgınının vahameti çok net görülmektedir ve bu durum çalışanlar açısından endişe vericidir. Ayrıca çalışmada, bu salgın ile birlikte dijital çalışanların kriz zamanlarında daha fazla arzu edilir olduklarının kesinlik kazandığı ortaya konmuştur.

Nastopoulous (2020, s. 21) tarafindan yapılan çalışmada, zorunlu karantina ve evde kalma sürecinde siparişlerini maskeler ve eldivenler gibi kişisel koruyucu ekipmanlarla erken sağlayan işletmelerin, bu sürece sadece adapte olduklarını ve problem çözdüklerini değil, aynı zamanda hem çalışanlarının hem de müşterilerinin sağlığının ve güvenliğinin kendileri için önemli olduğunu gösterdikleri belirtilmiştir. Ayrıca, pandemiyi ciddiye alarak, erken dönemde iş stratejileri için temel bir mercek olarak kullanan işletmelerin, bu akıllı karar verme süreçlerinin işletmenin sonuçlarının başarılı olmasını sağladığı da ifade edilmiştir.

Diğer taraftan bu süreçte, çeşitli işletmeler faaliyetlerini sürdürebilmek için, "sanal çözümler" (Perold, Bruwer ve Hattingh, 2020, s. 11) üretme çabası içerisine girmişlerdir. Bu süreç, çalışanların uzaktan çalş̧masına olanak sağlayan VDI (Vitual Desktop Infrastructure- Sanal masaüstü Altyapısı) sisteminin (Wangila, 2020, s. 1340) de işletmeler tarafından yaygın şekilde kullanılmasını sağlamışır.

Ayrıca, COVID-19 pandemisinin ortaya çıkardığı öngörülemeyen koşullar nedeniyle akademik çalışmaların (Bukhari, 2020, s. 36; Mia, 2020, s. 27; Pikalenko, 2020, s. 62; Salminen, 2020, s. 3) da yürütülmesi aşamasında bazı olumsuzluklar yaşandığı söylenebilir.

Iss Dünyası açısından COVID-19 'un İnsan Kaynaklar Üzrerindeki Etkisi. T.C. Aile, Çalışma ve Sosyal Hizmetler Bakanlığı’na bağlı İş Sağllğı ve Güvenliği Genel Müdürlüğü tarafindan her bir sektörde çalışana yönelik, COVID-19 pandemisinden korunmaya yönelik dikkat edilecek hususlar ile kontrol listeleri ayr1 ayrı yayınlanmıştır. Ayrıca, işletmelerin yasal zorunlulukları, işverenin alacağı önlemler ile COVID-19'a yönelik diğer bilgiler de kamuoyuna sunulmuştur (URL-6)

İnsan Kaynakları Yönetimi ve Örgütsel Davranıss konusunda uzman olan Dr Madeleine Petzer'in (2020, s. 6) "Coronavirus ve işgücü” konulu çalışmasında, pandemi sürecinde işletmelerin çoğunluğunun maliyetlerini azaltmak için çalışanlarını işten çıarabileceklerini ifade etmiştir. İngiltere'de COVID-19'un patlak vermesinden önce, William Hill, Centrica ve Jaguar Land Rover gibi birçok kuruluşun zaten büyük 
ölçekli işten çıkarma planları açıkladığı, ancak koronavirüs salgınının ekonomi üzerindeki olumsuz etkisi ile, dünya çapında kitlesel işten çıkarmaların yaşandığı da belirtilmiştir. Ayrıca, Petzer (2020), işten çıkarmaların uzun vadede işletme başarısını olumsuz etkileyeceğini ifade etmiştir. İşten çıkarma programlarından olumsuz etkilenenler arasında işten çıkarılmaktan kurtulanlar (işte kalan çalışanlar), mağdurlar (ayrılan çalışanlar) ve işten çıkarılma elçileri (işten çıkarmayla ilgili strateji, planlama, süreç, uygulama, iletişim ve istişareler gibi faaliyetler için sorumluluk üstlenenler) yer almaktadır.

Ayrıca, Koronavirüs'ün ardından, işten çıkarmaları ilk ilan eden sektörün havayolu endüstrisi olduğu ve 7.500 'den fazla çalışanın işini kaybedebileceği ifade edilmiştir. Diğer taraftan, pandeminin ağırlama endüstrisini de büyük ölçüde etkilediği ve binlerce servis personelinin de işten çıkarılma ile karşı karşıya olduğu ve hatta bu durumun işten çıkarmalar üzerinde bir kartopu etkisi oluşturacağının da beklendiği vurgulanmışır.

Türkiye'de 1986 yllından bugüne denetim, vergi, yönetim danışmanlı̆̆, kurumsal finansman ve kurumsal risk alanlarında hizmetler sunan Deloitte tarafından yayınlanan (URL-7) "COVID-19: Çalışanlara ve Çalışma Hayatına Olası Etkileri” başlıklı çalışmada, Uzaktan çalışma, dijital işgücü, mobilite, çalışan deneyimi ve motivasyonu, iş garantisi ve sürekliliği ile kapsayıcılık alt başlıkları ile COVID-19'un çalışanlar ve çalışma hayatına etkileri hakkında görüşler ortaya konulmuştur. Şöyle ki;

a) Esnek çalışma koşullarının en ön plana çıkan bileşenlerinden olan "uzaktan çalışmanın”, çalışanlar için kişisel sebepler ve kendi motivasyonlanı nedeniyle tercih sebebi iken, işletmeler için ise hem mali kazanımlar hem de çalışan bağıllığı sebebiyle tercih sebebi olduğu belirtilmiştir. Çalışanların bir kısmının, özellikle genç çalışanların, iş yerini yani çalışma ortamını sosyalleşmek, ileriye dönük ilişkiler geliştirmek, sosyal ağlar kurmak ve ortamı deneyimlemek adına bir firsat olarak gördükleri ifade edilmiştir. Bu nedenle bazı çalışanlar için uzaktan çalışmanın cazip gelmeyebileceği vurgulanmıştır. Ancak bu durumun sadece kuşak veya yaşla ilgili olmadığı aynı zamanda çalışanın içe dönüklük ya da dışa dönüklük gibi kişisel özelliklerinden de kaynaklanabileceği belirtilmiştir. Diğer taraftan uzaktan çalışma kavramı, korana virüs ile birlikte zorunluluk halini almıştır. Uzaktan çalışma ile birlikte şirketlerin karşı karşıya olduğu siber riskler artabilir. Birçok şirket uzaktan çalışma için gönüllü olsa bile, çok daha azı uygun siber güvenlik protokollerine ve altyapısina sahiptir.

b) Günümüzdeki çalışanlar açısından en büyük motivasyon unsurlarından biri olarak görülen mobilitenin, COVID-19 pandemisiyle birlikte, çalışıkları ofislerin veya fabrikaların, yaşadıkları şehirlerin ve ülkelerin ötesinde, çalşşma hayatlarını ve kariyerlerini çok daha geniş bir alana yaymış; kimisi dönemsel görevlendirmeler, kimisi ise - bazen uzun, bazen kısa - sürekli seyahatler ile böyle bir iş hayatına uyum sağlamış çalışanların seyahat yasakları ve kısıtları nedeniyle tamamen değişebileceğinden bahsedilmiştir. Örneğin, son yıllarda oldukça revaçta meslekler arasında yer alan pilotluğun artan trendinin değişebileceği belirtilmişsir. Ayrıca, bu süreçte bir yerden başka bir yere gitme yani fiziki bir ortamda bulunabilme durumunun uzaktan çalışabilmeye evrilebileceğine, bunun da beraberinde geleceğin çalışma modeline geçişi akıllara getireceğine değinilmiştir.

c) Çalışanların deneyimi ve motivasyonu ile ilgili; bir yandan sağlı̆ını, bir yandan da işini kaybetme kaygısını eş zamanlı yaşayanların olabileceği, özellikle çalşılan alan enfekte olma riskinin daha yüksek olduğu bir meslek ise (örnek: Sağlık çalışanları) çalsşanlarda endişenin artması, hatta bazılarında bunun panik moduna dönüşmesi, demotivasyon virüsünün; koronavirüsten bile daha hızlı yayllabileceği belirtilmiştir. Bununla birlikte, özellikle belirsizliğin çalışanlar üzerinde yaratacağı olumsuz etkileri en aza indirebilmek için şeffaf iletişimin her zamankinden çok daha önemli olacağ1, aksiyonlar ve alınan önlemlerle çalışanlarını gerçekten düşünerek hareket eden işletmelerin bu süreçte değerlerini daha da çok artıracağ 1 ifade edilmiştir.

d) İş garantisi ve sürekliliği ile ilgili; keskin bir şekilde talep düşmesi, tedarik zincirinde yaşanan problemler, işgücü devamsızlı̆ı gibi tetikleyicilerin yarattı̆̆ı olumsuz koşullar nedeniyle birçok sektör çok büyük yaralar alabilir. Şirketler, finansal süreklilik sağlandığı durumda iş sürekliliğini, müşterileri ile bağlantıda kalarak, çalışanlarını anlayıp destekleyerek, tedarik zinciri sorunlarına çözümler geliştirerek, dijital yetkinlikleri güçlendirerek ve aynı ekosistemdeki diğer işletmelerle iletişim halinde kalarak devam ettirmeliler. Online satış kanalları, teknoloji uygulamaları, uzaktan çalısma altyapısı bulunmayan şirketleri bu süreçte doğal olarak daha fazla zorluk bekliyor. Küçülme yaşayacak veya faaliyetlerine son verecek şirketlerin çalışanları için ise hükümetler devreye girmelidir. Tüm bunlar gerçekleşirken, özellikle iş kanunu açısından çalışanı ve işvereni ilgilendirebilecek bazı başlıklar gündemi epey meşgul edebilir. Bu başlıklar şöyle sıralanabilir: 
- Telafi izni

- Ücretli izin

- Ücretsiz izin gibi izin düzenlemeleri

- İş akdi feshi

- Hastalık masraflarının karşılanması

e) Ayrıca kapsayıc1lı ile ilgili; günümüz iş dünyasında liderlik, değerler ve kültür açısından "kapsayıclık" kavramının sürekli ön planda olduğu belirtilmiştir. Buna göre, işletmelerin aldığı önlemlerde ve hayata geçirdiği aksiyonlarda çalışanları arasında "ayırma" ve "kayırma" tuzaklarına düşmemesi gerektiği vurgulanmıştır. Bununla birlikte, üretim yapan işletmelerde beyaz yakalı çalsşanın evden çalşsma modeline geçmesinin, mavi yakalı çalışanın ise üretimi sürdürme adına fabrikalarda çalışmaya devam etmesinin hem "ayrımcllık" kavramını akıllara getirdiği; hem de işletmelerin birçoğunun geleceğin çalışma modeline hazırlıklı olmadığını gösterdiği belirtilmiştir.

Diğer taraftan, çalışanlarına mümkün olduğunca eşit hakları sağlayan işletmelerin, bu dönemde ilgi odağ1 olacakları ve belki de ilerisi için daha çok tercih edilecekleri ifade edilmiştir. COVID- 19 küresel sağlık kriziyle birlikte, tüm mavi yakalı ve beyaz yakalı çalışanların işlevleri ve çalışma şekilleri baştan ayağa değişmektedir. Son zamanlarda, bilgi teknolojisi sektöründe çalışan gri yakalı çalışanlar da bu tanımlara eklenmiştir (Şen, 2020, s. 197).

Ayrıca, İş Hukuku açısından COVID-19 pandemisinin insan kaynakları üzerindeki etkisini ele alan ve söz konusu krizin doğurduğu ve/veya doğurabileceği etkiler ile tavsiyelere ilişkin Avukat Hatice Arabac1 tarafindan yapılan bir çalışmada (URL-8);

- İşverenin çalışanı yurtdışı iş seyahatlerine göndermemesi, yurtiçi seyahatlerde ise çalışanın psikolojik olarak zarar görecek olması halinde seyahate gitmeye zorlanamayacağ1,

- İşverenlerin çalışanlarını tıbbi muayeneden geçmeye zorlayamayacağı ancak çalısanlarından "risk unsuru" olduklarına ilişkin bir beyan talep edebileceği,

- Enfekte olan çalışanların risk unsuru olduklarını işverenlerine bildirmeleri gerektiği, işyerinde enfekte olan çalışanların ise durumunun iş kazası olarak değerlendirilebileceği,

- İşyerinde COVID-19 enfeksiyonun teyit edilmesi gibi ciddi ve yakın bir tehlike ortaya çıkarsa, tehlike giderilinceye kadar çalışanların çalışmaktan kaçınabileceği,

- COVID-19 salgını nedeniyle çalışanlara onayları olmaksızın ücretsiz izin kullandırılamayacağı, yıllık izin hakkediş yılı dolmak üzere olan çalışanlara yıllık izin kullandırılabileceği, diğer çalısanlar açısından yıllık izin kullanımı yalnızca tavsiye niteliğinde olacağı, niteliği uygun işler açısından çalışanlara bildirilip onay alınarak evden çalışma yaptırilabileceği,

- İşyerinde, genelge ile işyerinin kapatılması gibi sebeplerle zorlayıcı neden oluştuğunda çalışanların iş sözleşmesinin söz konusu süre için askıya alınıp ve bu süre boyunca çalışana yarım maaş ödenebileceği COVID-19 nedeniyle işyerinin kapatılması halinde işçiye haklı nedenle fesih hakkı oluşturacağ 1 ,

- COVID-19 nedeniyle işin durması ya da çalışmanın azalması halinde, iş yerinin normal çalışma dönemine başlamasını takip eden 4 ay içerisinde telafi çalışması yaptırılabileceği,

- İşyerinde çalışmanın tamamen durması ya da en az $1 / 3$ oranında azalması halinde işverenin kısa çalışma ödeneğine başvurabileceği, kısa çalışma ile çalışılmayan sürelerde işçilere işsizlik sigortası fonundan gelir desteği sağlanacağı,

- Çalışanın çevresinde işe gelmesini engelleyen zorlayıcı neden oluşması halinde ise işverenin, iş akdini kıdem tazminatı ödeyerek feshedebileceği belirtilmiştir.

Uluslararası Çalışma Örgütü’nün 24.04.2020 tarihli yayınında (URL-9), COVID-19 pandemisinin turizm, havacılık, denizcilik ve balıkçılık, eğitim, sağlık, kamu acil hizmetleri, gıda ve tarım, otomotiv, tekstil, giyim, deri ve ayakkabı sektörleri ve diğer sektörlere olan etkisi ele alınmıştır. Buna göre;

- COVID-19'un Mart 2020'de dünyanın her köşesine hızla yayılmasından sonra, uluslararası turizmin tamamen durduğu, seyahat kısıtlamaları, havayolu uçuş iptalleri, turizm işletmelerinin kapatılması gibi önlemlerin hemen etki yarattı̆̆ belirtilmiştir. Öncelikle ulusal ve uluslararası turizm hizmetlerinin arz ve talebi büyük ölçüde düşmüsstür. Turizm sektörünün, tarım, ulaşım, el sanatları, yiyecek-içecek hizmetleri gibi sektörlerde önemli çarpan etkisine sahip olması nedeniyle, COVID-19 pandemisinin büyük zorluklara yol açtı̆̆ ifade edilmiştir. 
- Uluslararası tedarik zincirlerinin ana damarı olan, 2 milyon denizci çalışıran ve küresel ticaretin \%90'ını taşıyan deniz taşımacılığı sektörü, çeyrek milyon denizciyi istihdam eden gezinti gemiciliği sektörü ve on milyonlarca balıkçının çalıştığı deniz balıkçılığı sektörü COVID-19 krizinden özellikle ağır darbe almıştır.

- COVID-19 pandemisinin yayılmasını sınırlamak amacıyla, dünyanın çoğu ülkesinde okullar ve üniversiteler kapanmıştır. 192 ülkede zorunlu kapatma önlemi uygulanmıştır; yaklaşık 1.58 milyar öğrenci (kayıtlı öğrencilerin \%91,4’ü) için öğrenim faaliyetleri durmuştur, hemen hemen tüm eğitim sistemleri uzaktan eğitim çözümlerini kullanmaya başlamıştır. Bu aksama 63 milyon ilk ve orta öğretim öğretmeni ile çok sayıda eğitim destek personelinin işini de etkilemiştir.

Medyatik Açdan COVID-19'un İnsan Kaynaklar Üzerindeki Etkisi. Uluslararası medyada, Hindistan ile ilgili "Modi'nin COVID-19 kurtarma paketi Hintli göçmen işçiler için çok az şey ifade ediyor" başlıklı bir haberde (URL-10), COVID-19 pandemisi sebebiyle göçmen işçilerin yaşadığı dramatik zorluklar bir işçi tarafindan şöyle dile getirilmiştir:

"Bildiğimiz şey, karantina nedeniyle aç ve parasız kalmamızdır. Modi evde kalmayı söylüyor, evde kalırsak nasıl para kazanacağız, ne yiyeceğiz? Öleceğiz ve kimse rahatsız olmayacak". Bu habere göre, Başbakan Modi'nin 20 trilyon Rupi'lik kurtarma paketi büyük ölçüde göçmen işçileri istihdam eden işletmelerin ayakta durmasına yardımcı olmayı amaçlamışır. Yakındaki muhtaçlara yardım etmek için daha fazla tedbir alınmasına rağmen, göçmen işçilere gıda, konaklama ve ulaşım düzenlemeleri için eyaletlere yalnızca 132 milyon dolar tahsis edilmiştir. Yeterli olmayan yardımlardan dolayı binlerce göçmen işçi aç ve parasız bir şekilde yürüyerek köylerine geri dönmek istemişlerdir. Ancak, polis sınır bölgelerindeki binlerce göçmenin ayrılmasını engellediğinden çatışmalar başlamıştır. Hindistan'da yaşanan bu dramatik olaya ilişkin eleştirel anlamda bir çalışma yürüten Mohr (2020)'a göre, "Modi-COVID-19 varsayımsaldır! Bir açıdan COVID-19'dan varsayımla farklılık gösterir: Nüfusun tüm nesli için tüm yani kuşağı için aynı sağlık riskini oluşturur. Bu nedenle işgücü sağllğı gerçek COVID-19 salgınınınkinden daha tehlikelidir”. Mohr (2020) tarafindan aç1kça dile getirilen bu trajik ve dramatik durum online haber sitelerinde de açıça görülmektedir.

Ayrıca, İngiltere'ye yönelik 29.05.2020 tarihli The Guardian Haberleri (URL-11)'ne göre, Şansölye'nin, Covid-19 krizine yönelik desteğini çok daha temkinli, adım adım yaklaşmayı seçtiği ve aynı zamanda serbest çalışanlara üç ay daha destek verdiği görülmüştür. Ancak, işletmelerin birçoğunun COVID-19'dan önce bile ince Pazar marjları ile çalıştıkları ve mevcut sosyal uzaklaşma kuralları ile para kazanmalarının daha da zor olacağı belirtilmiştir. Şansölye, konaklama gibi bazı sektörlerin şu anda maaşların \%20'sini bile ödemeyecek durumda olduklarını vurgulamıştır.

Bununla birlikte, "COVID-19 iş hayatında kuralları değiştirdi" başlıklı bir diğer başka medya (dünya.com) haberinde (URL-12), salgın günlerinde işletmelerin çalışanlarına yönelik psikolojik danışma hattı, diyetisyen desteği ve spor dersleri verdikleri, bazı işletmelerin uzaktan veteriner desteği bile sağladıkları belirtilmiştir. Ayrıca, COVID-19 pandemisinde çalışanlarına destek olmak amacıyla bazı işletmelerin;

- Çalısanları, eş ve çocukları ile birinci derecede yakınları için online tıbbi danışmanlık (Örneğin, OYAK Doktorum hizmeti) hizmeti verdikleri,

- Çalışanlarına işten çıkarmama garantisi (Örneğin, Philip-Morris/ Sabancı) verdikleri,

- Evden çalışma düzenine geçtikleri ve üretim vardiyalarının yeniden düzenlendiği (Örneğin, Kibar Holding), bu bağlamda videolu mesajların, görüntülü görüşmelerin ve canlı yayınların sıklıkla kullanildığ1,

- Çalşanların motivasyonunun ve işletme içi sinerjinin artırlması amacıyla aile içi iletişim, ruh sağlı̆ı̆nı koruma, evden verimli çalışma, canlı bağlantı üzerinden spor eğitmenleri eşliğinde egzersiz, diyetisyen desteği (Örneğin, Turkcel) gibi aktivitelerin yapıldığı haberi verilmiştir.

Ayrıca, UNICEF’in 30.03.2020 tarihinde yayınladığ1 “COVID-19 tüm dünyayı etkisi altına alırken çalışan aileler için daha fazla destek gerekli” başlıklı çalışmasında (URL-13); COVID-19 krizi karşısında, istihdam ve gelir koruma tedbirleri, aile mensuplarının bakımı için ücretli izin, esnek çalışma düzenlemeleri ve kaliteli acil durum çocuk bakımına erişim dâhil olmak üzere benimsenecek aile dostu politikalar ve uygulamaların kritik bir fark yaratabileceği, bu tedbirler sayesinde ise çalışanların kendilerini ve çocuklarını koruyabileceği, onlara bakabileceği ve ayrıca çalışanların verimliliğinin ve güvenlik hissinin de geliştirilebileceği belirtilmiştir. 
Yukarıdaki tüm akademik çalışmalar ile iş dünyası ve medya görüşleri incelendiğinde; COVID-19 pandemisinin kısa süreli karantina (URL-3; Nastopoulous, 2020), sosyal uzaklaşma ya da sosyal iletişimi sinırlandirma (Ishak vd., 2020; Koirala ve Acharya, 2020; Krishnamurthy, 2020; Mia, 2020; Nastopoulous, 2020; Perold vd., 2020; Sengupta ve Bose, 2020; Stephens, 2020; Wen vd., 2020) ulusal veya uluslararas1 seyahat yasaklar1 (URL-3; Deloitte, 2020; Perold vd., 2020; Stephens, 2020), evde kalma (John-Eke ve Eke, 2020; Krishnamurthy, 2020; Nastopoulous, 2020; Stephens, 2020; Wen vd., 2020; Şen, 2020) evden çalışma (Simonen, 2020; Stephens, 2020; Koirala ve Acharya, 2020; Wangila, 2020), işletmelerin ve ofislerin kapatılmas1 (Haywood, 2020; Mia, 2020; John-Eke ve Eke, 2020), temel hijyen ilkelerinin (Perold vd., 2020) medya aracilığıla sürekli olarak duyurulması ve kamuya açık alanlarda maske takma (Wen vd., 2020) gibi önlemler yoluyla çalışanın ve toplumun sağlığının korunmaya çalışıldığı açıkça görülmektedir.

\section{Tartışma, Sonuç ve Öneriler}

Bu çalışmada COVID-19 pandemisinin insan kaynakları üzerine etkisi, akademi, iş dünyası ve medya perspektifinden incelenmiştir. Bu bağlamda, online yayınlanan akademik çalışmalar, iş dünyası görüşleri ile medyadaki diğer yayınlar incelendiğinde, COVID-19 pandemisi sonrasında insan kaynaklarına yönelik yönetsel eylem ve söylemlerin eskisi gibi olmayacağ1 söylenebilir. Çünkü, COVID-19 pandemisi sona erse bile insanlar, ev yaşamlarında, iş yaşamlarında ve diğer sosyal yaşamlarında sosyal mesafeyi koruma eğiliminde olacaklardır. Bazı kurallar değissecektir, geleneksellikten uzak iş yaşamı ve sosyal yaşam tercih edilecektir. $\mathrm{Bu}$ anlamda çalışanların $\mathrm{da}$ iş hayatında takım çalışmasından daha çok bireysel çalışma eğiliminde olabileceği söylenebilir. Ayrıca, COVID-19 pandemisiyle birlikte iş dünyasında beyaz ve mavi yakalı çalışana ek olarak "mobil bilgi işlem teknolojisini kullanarak evden çalışan" olarak tanımlanan (URL14) "açık yakalı çalışan" kavramının daha çok kullanılmaya başlanacağı görülmektedir. Dolayısıyla çalışanın iş ve iş yaşamına ilişkin tutum, talep ve beklentileri de farklılaşacaktır. Bazı işletme kuralları çalışanlar lehine daha esnek olacaktır. Sadece çalışanın bakış açısı değil aynı zamanda, işletmelerin de önceliği ve bakış açısı değişecektir. Gelecekte, işletmelerin önceliğinin iç sorunlar (ülke içi sorunların önceliği) vatandaşlar ve kendi çalş̧anları ile ilgili olacağı beklenmektedir. Dolayısıyla, bu durumun, birçok işletmenin geçmişte güvendiği "her ne pahasina olursa olsun küreselleşme" stratejisine doğrudan karşı olduğunu göstermektedir (Nastopoulous, 2020, s. 13). Benzer şekilde Ritter (2020, s. 171) tarafindan da belirtildiği gibi, insanlar yerel düzeyde yönetime odaklanacaklardır ve yeni koalisyonlar ve ağlar oluşturacaklardır. Ayrıca, çevreye duyarlı biyo-bölgeler, yüksek korumacı, ileri teknoloji, bilim temelli yerli toplumlar (sivil toplumlar) ortaya çıkacaktır.

COVID-19 pandemisinin insan kaynakları üzerine etkisinin belirlenmesi amaciyla yapilan bu çalışmada, online yayınlanan akademik nitelikteki çalışmaların incelenmesi, iş dünyası ve medyatik görüşlerin tümevarımsal olarak değerlendirilmesi sonucunda aşağıdaki öneriler sunulmuştur. Şöyle ki;

- COVID-19 pandemisi sürecinde insan kaynakları yöneticileri başta olmak üzere diğer hat yöneticileri tarafından çalışanlarla bağ kurulması (Koirala ve Acharya; 2020, s. 6; Muñoz-Pascual ve Galende; 2020, s. 16), açık ve etkin iletişim ile şeffaf (Nastopoulous, 202, s. 12) yönetimin gerçekleştirilmesi ve böylece çalışan bağlıllğının oluşturulması,

- Sosyal mesafenin korunmasi (URL-2),

- Koruyucu tibbi malzemenin sağlanmasi (URL-2),

- İşletme içerisinde hijyen kurallarının oluşturulması ve uygulanması (URL-2; Qasim ve Alavandi, 2020, s. 1731).

- Çalışanlara yönelik İş Sağlı̆̆1 ve Güvenliği önlemlerinin iyileştirilmesi (URL-2)

- İşlerin niteliğine göre evden çalısma (uzaktan çalışma) ortamının oluşturulması, uzaktan ve sanal çalışmaya yönelik eğitimlerin verilmesi (URL-8; Koirala ve Acharya, 2020, s. 6; Nastopoulous, 2020, s. 12; Qasim ve Alavandi, 2020, s. 1723),

- Kademeli çalışma saatlerinin getirilmesi (URL-3),

- Ücretli hastalık izni imkanlarının sağlanması (URL-3),

- İşletmelerin iş stratejilerini ve faaliyetlerini yeniden gözden geçirmeleri (Ting vd., 2020, s. 1),

- İşletmelerin çevrimiçi platformları kullanarak faaliyetlerini sürdürmeleri (Ting vd., 2020, s. 1),

- $\mathrm{Bu}$ süreçte yöneticiler tarafindan gerekirse çalışana temel destek yapılmasıyla vasıflı ve / veya vasıfsız personelin tekrar çalışmaya teşvik edilmesi,

- Yeni proje ve ürünler üretebilecek yeni fikirlerin geliştirilmesi amacıyla çalışanların güçlendirilmesi (Muñoz-Pascual ve Galende, 2020, s. 16), 
- Pandemi süresince ve sonrasında (Ting vd., 2020, s. 2) belirlenen iş firsatlarının değerlendirilmesi önerilebilir.

Ayrıca, COVID-19 pandemisi sürecinde ve sonrasında işten çıkarmaların önüne geçilmesi tamamen mümkün olmasa da aşağıda sırasıyla verilen ve Petzer (2020) tarafindan önerilen 10 eylemin işten çıkarmaların sınırladığı veya hatta önlediği düşünülmektedir. Bu önlemler;

- Panik yapılmaması ve aşırı tepki verilmemesi,

- Ürün veya hizmet hattının uyarlanması,

- Maliyet tasarrufu sağlayan diğer tüm önlemlerin yerine getirilmesi,

- Çalışanlarla açık iletişsim sağlanması ve çalışanlara danışmanlık yapilması,

- Çalışanlara esnek çalışma imkanının verilmesi,

- Ücret bordrosunun farklı şekillerde azaltılması,

- Güçlü liderlik sağlanması ve net bir vizyonun belirlenmesi,

- Çalışanların tanınması ve ödüllendirilmesi,

- Çalışanların yeniden organize edilmesi,

- Çalışanların eğitilmesi ve geliştirilmesi şeklinde başlıklar halinde ayrıntılı olarak değerlendirilmiştir.

Diğer taraftan, çalışanın bu ortamda yaşayabileceği tükenmişlik hissine yönelik, Türkiye Psikiyatri Derneği Ruhsal Travma ve Afet Çalışma Birimi (2020) tarafindan da belirtildiği üzere, çalışanın kendi durumunu işletme ile paylaşması ve gerekli durumlarda görev yeri/biçimi değişikliği ya da ara verme gibi taleplerle kendini tükenmişliğe karşı koruması; işletmenin de çalışanlarını tükenmişliğe karşı eğitip ve takip etmesi önerilmektedir.

Sonuç olarak, COVID-19 pandemisi küresel düzeyde yaşanmaktadır ve durum içinde birçok belirsizliği, karmaşıklığı, kararsızlığ ve değişkenliği de barındırmaktadır. Yani aslında içinde bulunulan ortam VUCA (VUCA- Volatile: Değişken; Uncertain: Kararsız; Complex: Karmaşık; Ambiguous: Belirsiz) (Kırpık, 2020, s. 30) ortamıdır. Petzer (2020, s. 6-7) tarafindan da belirtildiği üzere, tüm dünyanın karşılaştı̆̆ ve halen içinde bulunulan ve yaşanılan bu durum, bilinmeyen bir varlık olduğu için özellikle işletmeler için zorlayıcıdır. Bu salgının ne kadar ciddi hale geleceği veya hızlı bir şekilde patlayıp patlamayacağı bilinmemektedir. Bilinmeyen, korku ve panik yaratır. İşletmelerin bu durumu proaktif olarak ele alabilmeleri için mümkün olduğunca odaklanmış olmaları gerekir. Bu bağlamda, işletmelerin yöneticileri geri dönüşü olmayan bir noktaya gelene kadar beklememelidirler. Proaktif önlemler almalıdırlar ve hem kısa hem de orta vadeli stratejiler uygulamalıdırlar. En önemlisi de güvende ve dikkatli olmalıdırlar.

Ayrıca bu araştırmanın sınırlılıkları vardır. Literatür taraması sırasında; örneklem kapsamına dahil edilen bazı çalışmaların tam metin kısmında COVID-19 terimi geçmesine rağmen erişimlerinin ücrete tabi olmasi nedeniyle (Avni ve Rotem, 2020; BaniMelhem ve Elanain, 2020; Paché, 2020; Moaniba, Su ve Lee, 2020; Sharma, Moses, Borah ve Adhikary, 2020; Tan, 2020) bu yayınlara ulaşılamamıştır. Bununla birlikte, COVID-19 pandemisi sebebiyle evden çalışılması nedeniyle de diğer kurumsal veri tabanlarına ulaşmada da zorluk yaşanmıştır. Bu bağlamda, gelecekte yapılacak çalışmaların örneklem büyüklüğünün daha geniş olması, ulaşılan sonuçların geçerliliğini ve güvenilirliğini etkileyeceği için tüm bilimsel çalışmaların online ulaşıma açık ve ücretsiz olarak yayınlanması öneri olarak sunulabilir.

\section{Etik Beyan}

"COVID-19 Pandemisinin İnsan Kaynaklar Üzerindeki Etkisinin Akademi, Medya ve Isss Dünyası Perspektifinden Incelenmesi” başıklı çalışmanın yazım sürecinde bilimsel, etik ve alıntı kurallarına uyulmuş; toplanan veriler üzerinde herhangi bir tahrifat yapılmamış ve bu çalışma herhangi başka bir akademik yayın ortamına değerlendirme için gönderilmemiştir.

\section{Kaynakça}

Bukhari, S. M. M. (2020). Psychological Traits of Leaders in the World of Start-ups. Bachelor's Thesis, Tampereen ammattikorkeakoulu, Tampere University of Applied Sciences. https://www.theseus.fi/bitstream/handle/10024/336798/Bukhari\%2c\%20Syed\%20Muhammad\%20Mazhar.p df? sequence $=3 \&$ is Allowed $=\mathrm{y}$ 01.06.2020

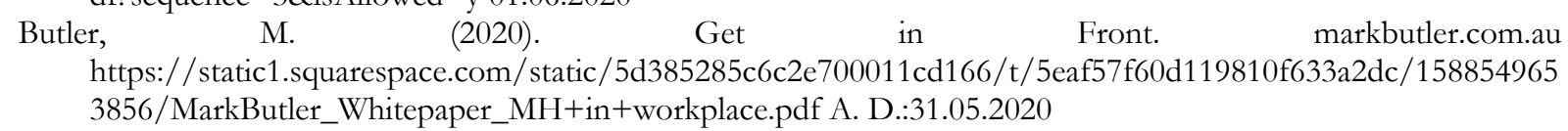


Haywood, M. (2020). A post-COVID future: tourism community reimagined and enabled, Tourism Geographies, DOI: $10.1080 / 14616688.2020 .1762120$ A. D.: 31.05 .2020

Hultman, K. (2020). Building a Culture of Employee Optimization. Organization Development Journal. https://s3.amazonaws.com/academia.edu.documents/63277276 01.06.2020

Ishak, S., Omar, A. R. C., and Osman, L. H. (2020). Sympathy and Benevolence of Business Entities: Evidence during the COVID-19 Pandemic Outbreak. International Journal of Academic Research in Business and Social Sciences, 10(5), 102-113.

John-Eke, E. C. and Eke, J. K. (2020). Strategic Planning and Crisis Management Styles in Organizations: A Review of Related Literature. Journal of Strategic Management, Vol. 5, Issue 1, pp 36-46.

Kırpık, G. (2020). “Örgütsel Davranış Çalışmalarında Yeni Kavramlar: Google Akademik (2019) ve SCI (2020) Veri Tabanlarına Yönelik Sistematik Literatür Taraması”, Örgütsel Davranış Üzerine Güncel Çalışmalar (Ed. Müjdat Avcı ve Ergün Kara). İstanbul: Hiperyayın.

Koirala, J. and Acharya, S. (2020). Dimensions of Human Resource Management Evolved with the Outbreak of COVID-19 (April 24, 2020). Available at SSRN: https://ssrn.com/abstract=3584092or http://dx.doi.org/10.2139/ssrn.3584092

Krishnamurthy, S. (2020). The Future of Business Education: A Commentary in the Shadow ofthe Covid-19 Pandemic, Journal of Business Research, doi: https://doi.org/10.1016/j.jbusres.2020.05.034 A.D.: 30.05.2020

Lahtinen, S. (2020). Reframing the Role of Companies in Sustainability- Toward business sustainability transitions. The Faculty of Management and Business of Tampere University, https:/ / trepo.tuni.fi/bitstream/handle/10024/121641/978-952-03-1559-7.pdf?sequence=5\&isAllowed=y 01.06 .2020

Mia, M. Y. (2020). Employee well-being and better organization performance. Bachelor's Thesis, Degree Programme in Hospitality, Tourism and Experience Management, Haaga-Helia University of Applied Sciences, https://www.theseus.fi/bitstream/handle/10024/336321/Employee\%20wellbeing $\% 20$ and $\% 20$ better $\% 20$ organisation $\% 20$ performance.pdf?sequence $=201.06 .2020$

Mohr, E. (2020). Modi-Covid19 Bio-Economic and -Politics Simulation, National Resource Protectionism, Lockdown, Citizen Loyalty, Workplace, Reorganization and Health-cum-Economic Policy Stabilization on the Road to Pandemics Defense Planning. http://www.ici.unisg.ch/wp-content/uploads/2020/04/Covid-19Modi.pdf 31.05.2020

Muñoz-Pascual ve Galende (2020). Ambidextrous Relationships and Social Capability as Employee Well-Being: The Secret Sauce for Research and Development and Sustainable Innovation Performance. International Journal of Environmental Research and Public Health, 17, 3072. https://www.mdpi.com/1660-4601/17/9/3072

Nastopoulous, C. (2020). A Scenario-Based Analysis on the Impact of COVID-19 on the Public Sector, Private Sector, and International Business. Senior Theses, University of South Carolina, Moore School of Business. https://scholarcommons.sc.edu/senior_theses/379/ A. D.: 30.05 .2020

Nguyen, N. (2020). Thematic analysis of the effects of COVID-19 on Vietnamese micro-entrepreneurs in the service business in Finland. https://www.theseus.fi/handle/10024/340094 A. D.: 30.05 .2020

Perold, I., Bruwer, J.P. and Hattingh, C. (2020). The Forced Cancellation of Four Jewel Events Amidst COVID-19 and Its Probable Influence on the Western Cape Economy: a Literature Review. Available at SSRN: https://ssrn.com/abstract=3604132 A.D.: 30.05.2020

Petzer, M. (2020). Coronavirus and the workforce: how can we limit redundancies? http://researchonline.limu.ac.uk/iFd/eprint/12960/1/coronavirus-workforceredundancies_20200402T170659.pdf 31.05.2020

Pikalenko, R. (2020). Corporate Social Responsibility in Restaurant Business with The Emphasis on Sustainability. Thesis of International Business Vaasan Ammattikorkeakoulu University of Applied Sciences. https://www.theseus.fi/bitstream/handle/10024/339561/CSR\%20in\%20Restaurant\%20Business. \%20Bock\% $27 \mathrm{~s} \% 20$ Corner $\% 20$ Case $\% 20$ Company.pdf?sequence $=2$ 01.06.2020

Qasim, M. and Alavandi, T.S.S. (2020). Exploring Adult Education\& Employee Motivation: A Reiteration of Theoretical Perspective. The Place Names Society of India, Volume 40, Issue 60, 1723-1733.

Ritter, A. (2020). The TUDAPOL Principle: The Way to Think Unlimited, Develop Agile, Produce and Operate Lean. https://books.google.com.tr/ 01.06.2020

Salminen, H. (2020). 'Those who tell stories rule society'-An ethnographic study of narrative leadership in an HR department. https://www.doria.fi/bitstream/handle/10024/177224/salminen_helen.pdf?sequence=2 01.06.2020

Sengupta, G. and Bose, P. (2020). Preparing for Post COVID-19 Sustainable Supply Chain. International Journal of Management, IT \& Engineering, Vol. 10, Issue 05, 200-209.

Simonen, R. (2020). Planning a New Wellness Trip Using Service Design Case: Geneesi. Thesis for a Master in Culture and Arts. https://www.theseus.fi/bitstream/handle/10024/339808/Simonen_Riikka_Service_Design_Wellness_Trip.pd f?sequence $=2$ \&isAllowed $=$ y 01.06 .2020

Stephens, A. (2020). "Case Studies on Special Topics in Accounting". Honors Theses. 1520. https://egrove.olemiss.edu/hon_thesis/1520 01.06.2020 
KIRPIK

COVID-19 Pandemisinin İnsan Kaynakları Üzerindeki Etkisinin Akademi, Medya ve İş Dünyası Perspektifinden

İncelenmesi

Supardi and Hadi, S. (2020). New Perspective on the Resilience of SMEsProactive, Adaptive, Reactive from Business Turbulence: A Systematic Review. Journal of Xi'an University of Architecture \& Technology, Volume XII, Issue $\mathrm{V}, 1265-1275$.

Şen, E. (2020). Global Virus of the Digital Village COVID-19 and Senism. Eurasian Journal of Researches in Social and Economics, 7 (3), 176-204.

Ting, H., Ling, J. and Cheah, J. H. (2020). Editorial: It Will Go Away!? Pandemic Crisis and Business in Asia. Asian Journal of Business Research, Volume 10, Issue 1, pp 1-7. DOI: 10.14707/ajbr.190072

Wangila, F. (2020). Organizational Cyber-Security Measures During COVID-19 Epidemic. International Journal of Innovative Science and Reserach Technology, Volume 5, Issue 3, 1340-1341.

Wen, J., Kozak, M., Yang, S. and Liu, F. (2020). COVID-19: potential effects on Chinese citizens' lifestyle and travel. Tourism Review, Vol. ahead-of-print No. ahead-of-print. https://doi.org/10.1108/TR-03-2020-0110 A. D.: 30.05 .2020

Yap, J. (2020). Average to Aces: Sharing Lives, Living Better Lives. books.google.com https://books.google.com.tr/books?hl=tr\&lr 01.06.2020Willig, C. (2008). A Phenomenological Investigation of Taking Part in 'Extreme Sports'. Journal of Health Psychology. Vol. 13, No. 5, 690-702.

\section{YARARLANILAN LINKLER}

URL-1:

https://tr.wikipedia.org/wiki/2020\%27de_T\%C3\%BCrkiye 07.06.2020

URL-2:

https://www.who.int/docs/default-source/coronaviruse/covid-1069-sprp-unct-guidelines.pdf 06.06.2020

URL-3:

ILO (2020). COVID-19 ve Çalışma Yaşamı: Etkiler ve Yanıtlar. https://www.ilo.org/wcmsp5/groups/public/--europe/---ro-geneva/---ilo-ankara/documents/briefingnote/wcms_740193.pdf 05.06.2020

URL-4:

https: / / www.google.com/search?q= $\% 22$ COVID $+19 \% 22 \% 2 \mathrm{C}+\% 22$ business + world $\% 22 \% 2 \mathrm{C}+\% 22 \mathrm{employee} \% 22$ \&oq $=\% 22 \mathrm{COVID}+19 \% 22 \% 2 \mathrm{C}+\% 22 \mathrm{business}+$ world $\% 22 \% 2 \mathrm{C}+\% 22 \mathrm{employee} \% 22 \&$ aqs $=$ chrome..69i57j69i6 013.1168j0j8\&sourceid $=$ chrome\&ie $=$ UTF-8 31.05.2020

URL-5:

https:/ / scholar.google.com/scholar?hl=tr\&as_sdt=0\%2C5\&q= $\% 22$ COVID $+19 \% 22 \% 2 \mathrm{C}+\% 22 \mathrm{business}+$ world $\% 2$ $2 \% 2 \mathrm{C}+\% 22 \mathrm{employee} \% 22 \mathrm{zbtnG}=31.05 .2020$

URL-6:

https://ailevecalisma.gov.tr/covid19 07.06.2020

URL-7:

Deloitte (2020). Çalışanlara ve Çalışma Hayatına Olası Etkileri. https://www2.deloitte.com/content/dam/Deloitte/tr/Documents/human-capital/covid-19-calisanlara-vecalisma-hayatina-olasi-etkileri.pdf 07.06.2020

URL-8:

Arabacı, H. (2020). İşçi İşveren İlişkisi Açısından Koronavirüs (Covid-19) Salgını. https://blog.lexpera.com.tr/isciisveren-iliskisi-acisindan-koronavirus-covid-19-salgini/ 07.06.2020

URL-9:

ILO (2020). COVID-19 ve Turizm Sektörü. https://www.ilo.org/ankara/areas-of-work/covid-

URL-10: 19/WCMS_742714/lang--tr/index.htm 07.06.2020

https://www.channelnewsasia.com/news/asia/modi-s-covid-19-rescue-package-means-little-to-indian-migrant1273283231.05 .2020

URL-11:

https://www.theguardian.com/politics/2020/may/29/chancellor-takes-a-softly-softly-approach-to-easing-covid-19crisis-support 31.05.2020

URL-12:

https://www.dunya.com/dunya 07.06.2020

URL-13:

UNICEF (2020). COVID-19 tüm dünyayı etkisi altına alırken çalışan aileler için daha fazla destek gerekli. https://www.unicef.org/turkey/bas $\% \mathrm{C} 4 \% \mathrm{~B} 1 \mathrm{n}-\mathrm{b} \% \mathrm{C} 3 \%$ BCltenleri/covid-19-t $\% \mathrm{C} 3 \% \mathrm{BCm}$ -

$\mathrm{d} \% \mathrm{C} 3 \% \mathrm{BC}$ nay $\% \mathrm{C} 4 \% \mathrm{~B} 1$-etkisi-alt $\% \mathrm{C} 4 \% \mathrm{~B} 1$ na-al $\% \mathrm{C} 4 \% \mathrm{~B} 1 \mathrm{rken}-\% \mathrm{C} 3 \% \mathrm{~A} 7 \mathrm{al} \% \mathrm{C} 4 \% \mathrm{~B} 1 \% \mathrm{C} 5 \% 9 \mathrm{Fan}$-aileler-

i\%C3\%A7in-daha-fazla-destek 07.06.2020

URL-14:

https://www.oxfordreference.com/view/10.1093/oi/authority.20110803100251466 08.08.2020. 


\section{EXTENDED ABSTRACT}

Coronavirus (COVID-19) pandemic, which started in Wuhan China in late 2019, has greatly affected both developed and developing countries due to the quarantine that hinders the global economy. The COVID-19 pandemic is a process in which the business world is forced to shutter. This crisis is unprecedented, the first and only crisis that directly affects every person in the world, it is devastating because the crisis has been neglected and its impact can be fatal. It hit the business world in an unprecedented size and speed. The negative consequences of COVID-19 made businesses vulnerable. During this period, most businesses' activities were temporarily suspended and only businesses that provide basic services were allowed to continue their activities. Therefore, the COVID-19 pandemic has caused and will continue to be a multidimensional impact and change on business and human resources globally. In this process, the employees were either dismissed or sent to leave. In some countries social benefits or other cash transfers are made to increase income security and total demand.

As one of the biggest problems of the COVID-19 pandemic in the future, it is seen that managers cannot contact their employees or employees cannot communicate with each other. In this crisis environment, how can employees feel comfortable while trying to guarantee their health and safety in a physical place? What are some of the important effects this devastating crisis has brought to the business world? Questions like are some of the questions that come to mind in business and academic world. The subject of changing the working conditions of the future human resource due to the COVID-19 Pandemic is among the important topics that are currently being discussed with scientific researches, television programs, columns, online meetings and similar studies, both nationally and internationally.

The purpose of this study is to determine how the business conducts and business attitudes of the important and variable human resources of businesses, which are the lifeblood of the economy, are affected or may be affected due to the COVID-19 pandemic experienced globally. In this context, a qualitative review has been made through the opinions and publications in academia, the media and the business world to investigate the effects of COVID-19 outbreak on human resources and its possible future effects. In this context, in order to reach the purpose of the study, firstly, literature review was made. When the terms "COVID 19", "business world", "employee" are entered into the Google search engine, approximately 767,000 publications have been reached. Within this main mass, there are all publications related to media magazines, business world or academic studies. However, academic publications were given priority in order to increase the scientific quality and quality of the study. In this context, 62 academic studies were reached by writing the same terms in the Google Academic database for academic studies. In terms of the reliability of the literature review, the search process was repeated several times and the result was again in the form of 62 academic publications. Articles were examined according to "COVID 19", "business world", "employee / worker" criteria for including or excluding studies. As a result of the examination, 14 academic studies constituted the sample of the study for academic studies.

The findings obtained from the study revealed that the COVID-19 pandemic causes mass layoffs worldwide, the industry that declared the layoffs first is the airline industry, and the hospitality industry is also greatly affected, and this will have a snowball effect on layoffs. In addition, it has been determined that various enterprises have attempted to produce "virtual solutions" in order to continue their activities, and in this context, they have started to use the VDI (Vitual Desktop Infrastructure) system, which enables employees to work remotely. In this process, it has been observed that working remotely has become the preferred reason for businesses in terms of both financial gains and employee loyalty. However, it can also be said that some of the employees, especially young employees, see the workplace, namely the working environment as an opportunity to socialize, develop forward-looking relationships, set up social networks and experience the environment, so working remotely may not be attractive for some employees.

In addition, according to the findings of the study, it has been observed that mobility, which is considered as one of the biggest motivation factors for today's employees, may change completely with the COVID-19 pandemic due to the travel bans and restrictions of the employees. On the other hand, regarding the experience and motivation of the employees; On the one hand, there may be those who live simultaneously with the anxiety of losing their job, and on the other hand, especially if the area being studied is a profession where the risk of infection is higher (for example: healthcare professionals), anxiety in workers, even turning it into panic mode, demotivation virus; It was found that it can spread even faster than coronavirus. 
As a result, it can be said that when the academic studies, business world views and other publications in the media are analyzed online, after the COVID-19 pandemic, administrative actions and discourses about human resources will not be the same. Because even if the COVID-19 pandemic ends, people will tend to maintain social distance in their home, business and other social lives. Some rules will change, business life and social life far from traditional will be preferred. In this sense, it can be said that employees may tend to work more individually than in team work. In addition to the white and blue collar employees in the business world with the COVID-19 pandemic, it is seen that the concept of "open collar employee", which is defined as "working from home using mobile computing technology", will be used more. Therefore, the attitudes, demands and expectations of the employee regarding business and work life will also differ. Some business rules will be more flexible in favor of employees. Not only the perspective of the employee, but also the priority and perspective of the enterprises will change.

In order to reduce the negative impact of the COVID-19 pandemic on human resources and to maintain the physical and mental well-being of the employee in this process; During the COVID-19 pandemic process, establishing a bond with employees by other line managers, especially human resources managers, realizing transparent management with clear and effective communication, thereby establishing employee loyalty, maintaining social distance, providing protective medical equipment, creating and applying hygiene rules within the enterprise, Improving Occupational Health and Safety measures for employees, creating a working from home (distance working) environment according to the nature of the jobs, introducing gradual working hours, providing paid sick leave opportunities, developing new ideas that can produce new projects and products, strengthening employees, during and after the pandemic evaluation of opportunities is suggested. In addition, although it is not entirely possible to prevent layoffs during and after the COVID-19 pandemic, some actions and layoffs are thought to be limited or even prevented, and information was provided on those actions.

However, the COVID-19 pandemic is experienced at a global level and includes many uncertainties, complexities, instability and variability. In other words, the current environment is VUCA (VUCAVolatile; Uncertain; Complex; Ambiguous). This situation, which the whole world faces and still lives and experiences, is especially challenging for businesses since it is an unknown asset. It is not known how serious this epidemic will become or whether it will explode quickly. Unknown creates fear and panic. Businesses need to be as focused as possible in order to proactively address this situation. In this context, the managers of the businesses should not wait until they reach an irreversible point. They should take proactive measures and implement both short- and medium-term strategies. Most importantly, they should be safe and careful. 